\title{
Root surface colonization of non-cereal crop plants by pleomorphic Azospirillum brasilense Cd
}

\author{
Yoav Bashan, ${ }^{1} \uparrow$ Hanna LeVANONY ${ }^{2}$ and Robert E. WhitMoyer ${ }^{3}$ \\ ${ }^{1}$ Department of Agronomy, Ohio State University, Columbus, OH 43210, USA \\ ${ }^{2}$ Department of Plant Genetics, The Weizmann Institute of Science, Rehovot, Israel \\ ${ }^{3}$ Electron Microscopy Laboratory, Ohio Agricultural Research and Development Center, Wooster, OH 44691, USA
}

(Received 22 February 1990; revised 28 August 1990; accepted 4 September 1990)

\begin{abstract}
Root surface colonization by Azospirillum brasilense $\mathrm{Cd}$ of tomato, pepper and cotton plants under normal growth conditions and soybean plants under normal and water-stress conditions was monitored by scanning electron microscopy and bacterial counts. $A$. brasilense $C d$ was capable of efficiently colonizing the elongation and root-hair zones of all four plant species tested. In these zones, the bacteria mainly colonized the root surface (tomato, soybean), root-hairs (pepper), or both (cotton), by single cells (tomato, soybean), micro-aggregates (pepper), or a combination of the two (cotton). All inoculated plants demonstrated (i) larger amounts of mucigel-like substance on the root surface than non-inoculated plants and (ii) fibrillar material which anchored the bacterial cells to the root surface and established connections between cells within bacterial aggregates. On non-water-stressed soybean plants, most $A$. brasilense $C d$ cells in the rhizosphere occurred as vibroid forms whereas those on water-stressed plants (wilting) were cyst-like. A lower rhizosphere bacterial population was observed on water-stressed plants. When water-stress conditions were eliminated, the bacterial cells reverted to the vibroid form and a concomitant increase in the bacterial population was observed. It is suggested that cyst-like formation is a natural response for A. brasilense $\mathrm{Cd}$ in the rhizosphere of water-stressed plants.
\end{abstract}

\section{Introduction}

Inoculation of plants with putative beneficial rhizosphere bacteria of the genus Azospirillum has been carried out almost exclusively on a large variety of cereals (Bashan \& Levanony, 1990; Patriquin et al., 1983), although a few studies have focused on the interaction of Azospirillum with other plant species such as mustard (Saha et al., 1985), tomato (Bashan \& Levanony, 1988c; Bashan et al., 1989a, b), beet (Kolb \& Martin, 1985), soybean (Bashan et al., 1990; Plazinski \& Rolfe, 1985; Singh \& Subba Rao, 1979), sweet potato (Crossman \& Hill, 1987) or weeds (Bashan \& Levanony, 1987). Recently, it was shown that inoculation of tomato, pepper, eggplant and cotton plants with Azospirillum brasilense Cd significantly, but inconsistently, increased plant yield (Bashan et al., 1989a).

$\dagger$ Present address: Department of Microbiology, Centro de Investigaciones Biologicas de Baja California Sur, La Paz, Apdo Postal 128, BCS, Mexico 23000.

Abbreviation: SEM, scanning electron micrograph.
When inoculated onto cereal roots, $A$. brasilense $\mathrm{Cd}$ multiplies and forms small aggregates, mainly in the root elongation and root-hair zones (Bashan et al., 1986). The bacteria produce holdfast fibrillar material which anchors the cells to the root surface (Levanony et al., 1989).

Azospirillum cells appear in two distinct forms: the slightly vibroid form (V-form) occurring in young laboratory cultures and on plant roots (Berg et al., 1979; Tarrand et al., 1978), and the cyst form (C-form), occurring under stress or in old laboratory cultures (Bleakley et al., 1988; Eskew et al., 1977; Lamm \& Neyra, 1981 ; Sadasivan \& Neyra, 1985, 1987). The Cform may be a survival structure.

The aims of the present study were (i) to evaluate the ability of $A$. brasilense $\mathrm{Cd}$ to colonize root surfaces of several non-cereal plants and to determine colonization sites, (ii) to examine the occurrence of, and conditions for, pleomorphic $\boldsymbol{A}$. brasilense $\mathrm{Cd}$ in the rhizosphere, and (iii) to evaluate whether bacterial fibrillar connections to root surfaces are a general mode of attachment of $A$. brasilense $\mathrm{Cd}$ to plant root surfaces. 


\section{Methods}

Organisms. Azospirillum brasilense Cd (ATCC 29710) and the following plant species were used: tomato (Lycopersicon esculentum Mill.) cv. Na'ama; pepper (Capsicum annuum) cv. Ma'or; cotton (Gossypium barbadense) cv. Pima S-5; wheat (Triticum aestivum) cv. Deganit, and soybean (Glycine max) cv. Pella.

Seedling growth conditions. All seedlings except soybean were grown in $500 \mathrm{ml}$ pots, using sterile, coarse-type vermiculite which had been fertilized before sowing by soaking with sterile half-strength Hoagland's nutrient solution. The pots were placed in a Conviron model EF7 growth chamber (Controlled Environment Co., Canada) [14 h light $\left(150 \mu \mathrm{E} \mathrm{m}^{-2} \mathrm{~s}^{-1}\right), 10 \mathrm{~h}$ dark at $\left.28 \pm 2{ }^{\circ} \mathrm{C}\right]$ for $5 \mathrm{~d}$ after seedling emergence. Soytean seedlings were grown in $800 \mathrm{ml}$ pots in a similar manner under greenhouse conditions $\left(27 \pm 4^{\circ} \mathrm{C}\right.$ day, $20 \pm 4{ }^{\circ} \mathrm{C}$ night). Irrigation was carried out daily with sterilized water $(15-20 \mathrm{ml}$ per pot). Cyst-like forms of $A$. brasilense $\mathrm{Cd}$ on root surfaces were induced by stopping irrigation for $8 \mathrm{~d}$, until the plant leaves showed first wilting symptoms. Then, irrigation was renewed.

Definition of bacterial $V$ - and $C$-forms. Bacterial cells observed in photomicrographs of root surfaces were defined according to their size and the ratio of length to width. V-form bacteria had a length $(L)$ of $1.45 \pm 18 \mu \mathrm{m}$, a width $(W)$ of $0.408 \pm 0.092 \mu \mathrm{m}$ and an average ratio $(L / W)$ of $3.554: 1$ (mean of 228 measurements). C-form bacteria were defined as shorter and thicker cells with a length of $0.722 \pm 0.086 \mu \mathrm{m}$, width of $0.59 \pm 0.11 \mu \mathrm{m}$ and an average ratio $(L / W)$ of $1.224: 1$ (mean of 209 measurements)

Seedling inoculation. A. brasilense $\mathrm{Cd}$ was cultured in nutrient broth (Difco) medium (16 h, 250 r.p.m., $30 \pm 1{ }^{\circ} \mathrm{C}$ ), harvested by centrifugation, and washed twice with sterile $0.06 \mathrm{M}$-potassium phosphate buffer, $\mathrm{pH} 7 \cdot 1$, supplemented with $0 \cdot 15 \mathrm{M}-\mathrm{NaCl}$ (PBS); the number of bacteria was then adjusted to $10^{6}$ c.f.u. $\mathrm{ml}^{-1}$ [Bashan (1986) demonstrated a marked effect on the growth of wheat seedlings by this concentration of cells]. Seeds were immersed in the bacterial suspension in a mild vacuum for $30-60 \mathrm{~min}$. The vacuum was released abruptly to enhance bacterial penetration into seed cavities. The seeds were imbibed for an additional $16 \mathrm{~h}$ in the bacterial suspension at ambient temperature to ensure colonization of the germinating seeds before sowing.

Bacterial counts. Root tips, elongation, differentiation and root-hair zones, and older root parts were defined as previously described (Levanony \& Bashan, 1989; Levanony et al., 1989) using a stereoscopic microscope. Each root section was excised separately with a razor blade, and placed in $2.5 \mathrm{ml}$ PBS. The root tip and the differentiation and elongation zones were excised together. A. brasilense $\mathrm{Cd}$ cells attached to the outer surface of the roots were released into the buffer by light sonication of the sample (Branson Sonifier B-12 for $3 \mathrm{~min}$ at $10 \mathrm{~W}$ ). This sonication did not affect the multiplication of $A$. brasilense Cd (Bashan \& Levanony, 1989a). The suspension was plated on BL semi-selective $\mathrm{N}$-free medium (Bashan \& Levanony, 1985) using a spiral plater (Spiral Systems, Cincinnati, USA), and incubated for $72 \mathrm{~h}$ at $30 \pm 2{ }^{\circ} \mathrm{C}$ before counting. A. brasilense $\mathrm{Cd}$ was identified according to the descriptions of this strain made by Bashan et al. $(1989 \mathrm{~b})$ and Eskew et al. (1977). The level of sample contamination by other rhizosphere bacteria varied and was low, ranging from $1.2 \times 10^{1}$ to $4.4 \times 10^{2}$ c.f.u. per root sample. No attempt was made to identify the contaminants

Desiccation survival tests. (a) From liquid culture. Bacterial cultures ( $16 \mathrm{~h}, \mathrm{~V}$-forms; $96 \mathrm{~h}, \mathrm{C}$-forms) were grown as described previously (Bashan, 1986; Bashan \& Levanony, 1985). A $100 \mu \mathrm{l}$ bacterial suspension was placed on a thin, acetone-cleaned, dry, microscope cover-glass and air-dried at ambient temperature $\left(23 \pm 2{ }^{\circ} \mathrm{C}\right)$. The cover glasses were transferred to hermetically sealed glass containers together with silica gel (to absorb moisture) for $7 \mathrm{~d}$. Surviving bacterial cells were counted by immersing the cover glass in an Eppendorf microtube filled with nutrient broth, shaking for $3 \mathrm{~h}$, and enumerating bacteria as described earlier.

(b) From soybean roots. Inoculated roots were harvested $2 \mathrm{~d}$ after seedling emergence for recovery of $\mathrm{V}$-forms and $8 \mathrm{~d}$ after emergence plus water stress for recovery of $\mathrm{C}$-forms. The root elongation zone was excised and the segments were dried in a forced-air oven at $30 \pm 2{ }^{\circ} \mathrm{C}$ for $12 \mathrm{~h}$ and then transferred to the same sealed glass container as used for the liquid cultures. Bacteria were recovered from the root segments and counted as described earlier

Mucilage extraction. This was done according to Mandimba et al. (1986), using 250 seedlings per treatment. Results are expressed as $\mathrm{ml}$ extracted mucilage per 250 seedlings.

Scanning electron microscopy. Roots were fixed for $4 \mathrm{~h}$ in $5 \%(\mathrm{v} / \mathrm{v})$ glutaraldehyde in $0.2 \mathrm{M}$-cacodylate buffer, $\mathrm{pH} 7 \cdot 2$, under vacuum, washed twice in the same buffer and dehydrated by passage through increasing alcohol concentrations at $4 \pm 1{ }^{\circ} \mathrm{C}$. The samples were dried in a critical-point dryer (Tousimis Co., USA) in a $\mathrm{CO}_{2}$ atmosphere. The dried samples were affixed to stubs with carbon cement, coated with platinum (10-15 nm thickness; $25 \mathrm{~mA}, 2 \mathrm{~min}$, SEM Sputter Coating Unit E 5100, Polaron Equipment USA) and examined by Philips SEM 505 and ISI 40 scanning electron microscopes at $20-30 \mathrm{kV}$.

Experimental design and statistical analysis. Experiments were performed in random design with three to five replicates each, and repeated twice. A replicate consisted of either four seedlings, two electron microscopy stubs which contained three to five root segments each, two cover glasses, or two pots containing four seedlings each, according to the experiment. Significance was tested at $P \leqslant 0.05$ in Fisher's Least Significant Difference (LSD) test or by standard error.

\section{Results}

Root colonization of tomato, pepper and cotton plants by pleomorphic $A$. brasilense $C d$

Observations carried out along inoculated tomato roots, followed by bacterial counts, revealed that the majority of the surface bacterial population was concentrated in the elongation and the root-hair zones (Table 1, Fig. $1 a$ ), although single cells were randomly located and enumerated in the older parts of the root system. The main distribution pattern on tomato roots was in the form of single cells (Fig. $1 b, c$ ). The bacteria were located on the bases of the root-hairs; however, the root-hairs themselves were generally free of bacteria (Fig. $1 d$ ). Some $A$. brasilense $\mathrm{Cd}$ cells had the typical vibroid shape, and others had a relatively thick fibrillar material connecting them to the roots (Fig. 1e). In order to rule out the possibility of contamination by other bacterial species with different morphology, a similar experiment with tomato roots was performed two years later under axenic conditions, with similar results. The same inoculum gave the normal bacterial morphology, i.e. lacking thick fibrillar material, when colonizing wheat roots (Bashan et al., 1986) (data not shown). A larger amount of mucilaginous substances $(2 \cdot 1 \mathrm{ml})$ was recovered from 

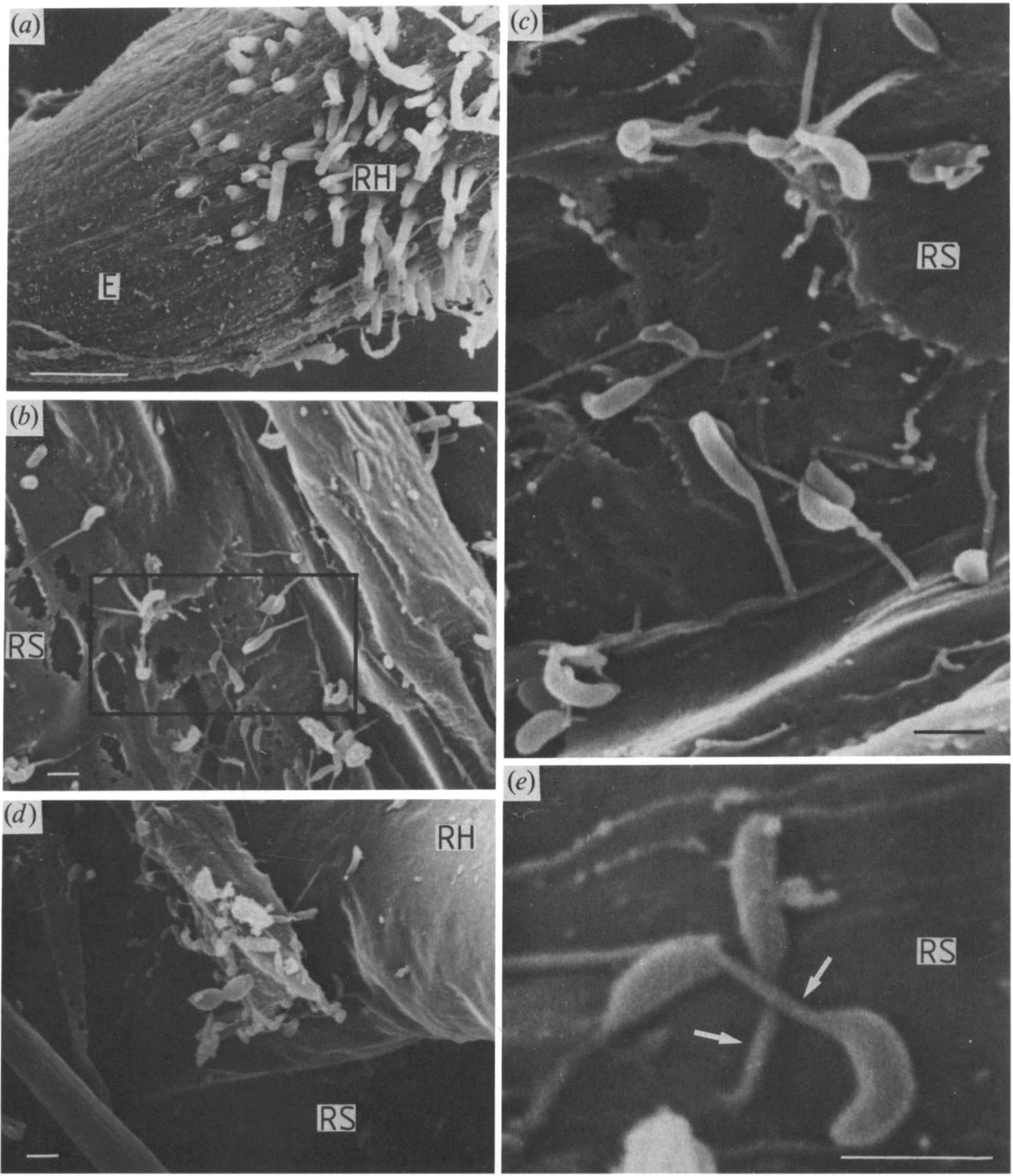

Fig. 1. Scanning electron micrographs (SEMs) of tomato root colonization by $A$. brasilense Cd. (a) Location of the bacterial population in the elongation and root-hair zones; (b) typical presence of bacteria as single cells on root surfaces; (c) enlargement of (b) showing bacteria randomly dispersed on the root surface; $(d)$ bacteria located on the base of root-hairs; $(e)$ vibroid shape of root-colonizing bacteria; arrows indicate thick fibrillar material connecting bacterial cells to root surface. Bars represent $1 \mu \mathrm{m}(b-e)$ and $0 \cdot 1 \mathrm{~mm}(a)$. Abbreviations (also used in the other electron micrographs): C, cyst-like bacteria; E, elongation zone; F, fibrillar material; RH, roothair; RS, root surface; V, vibrio-form bacteria. 
Table 1. Colonization of different root parts by $A$. brasilense $C d 18 d$ after inoculation

\begin{tabular}{lccc}
\hline \multicolumn{3}{c}{$\begin{array}{c}\text { Colonization by } A . \text { brasilense Cd } \\
\left.\text { [c.f.u. (cm root) }{ }^{-1}, \pm \mathrm{SE}\right]^{*}\end{array}$} \\
\cline { 2 - 4 } $\begin{array}{c}\text { Plant } \\
\text { species }\end{array}$ & $\begin{array}{c}\text { Elongation zone }+ \\
\text { differentiation zone } \\
+ \text { root tip } \dagger\end{array}$ & $\begin{array}{c}\text { Root-hair } \\
\text { zone }\end{array}$ & $\begin{array}{c}\text { Older } \\
\text { root }\end{array}$ \\
\hline Tomato & $3.6 \pm 0.7 \times 10^{5}$ & $1.1 \pm 0.3 \times 10^{5}$ & $2.9 \pm 0.7 \times 10^{3}$ \\
Pepper & $3.1 \pm 0.3 \times 10^{5}$ & $4.4 \pm 0.4 \times 10^{5}$ & $3.6 \pm 0.4 \times 10^{3}$ \\
Cotton & $7.2 \pm 0.5 \times 10^{5}$ & $6.7 \pm 0.4 \times 10^{5}$ & $1.4 \pm 0.4 \times 10^{3}$ \\
Soybean & $5.2 \pm 0.8 \times 10^{5}$ & $4.3 \pm 0.7 \times 10^{5}$ & $2.2 \pm 0.9 \times 10^{3}$ \\
Wheat & $2.1 \pm 0.4 \times 10^{4}$ & $2.7 \pm 0.5 \times 10^{4}$ & $6.1 \pm 0.6 \times 10^{2}$ \\
\hline \hline
\end{tabular}

* The results are means of two experiments, each with three replicates, four plants per replicate.

† Using the method described by Levanony \& Bashan (1989). Measured from root tip until first appearance of root hairs.

$\ddagger$ Root section above the root hair zone.

inoculated tomato plants compared to non-inoculated plants $(1.3 \mathrm{ml})$.

Inoculation of pepper seedlings with $A$. brasilense $\mathrm{Cd}$ resulted in enlargement of the elongation and differentiation zones compared to non-inoculated pepper seedlings $(1.95 \pm 0.32 \mathrm{~mm}$ versus $0.76 \pm 0.19 \mathrm{~mm}$; means of 28 samples, $\pm \mathrm{SE}$ ) observed. In addition, a larger amount of mucilaginous substances was recovered from inoculated roots and root-hairs $(1.8 \mathrm{ml}$ versus $1.1 \mathrm{ml}$ per 250 seedlings). Unlike tomato roots, colonization was mainly on the surface of root-hairs (Fig. $2 b, c$ ), although some bacteria were also found on the root surface in the root hair zone (Table 1, and Fig. 2a). The typical mode of colonization was aggregate formation, each aggregate containing several cells (Fig. $2 d, e$ ) and the microcolonies on the root-hairs were usually larger than those on the root surface (Fig. $2 f$ ). The formation of the thick fibrillar material at the poles of the bacterial cell was also observed on pepper roots (see Fig. $2 a, c, e$ ).

Inoculation of germinating cotton seedlings with $A$. brasilense $\mathrm{Cd}$ resulted in the heaviest visible surface colonization of the four plant species tested. The main bacterial population was observed, as in the other plant species, in the elongation and root-hair zones (Table 1). The interaction between $A$. brasilense $\mathrm{Cd}$ and cotton roots produced a larger amount of mucilage-like material than that recovered from non-inoculated plants $(2.7 \mathrm{ml}$ versus $1.4 \mathrm{ml}$ ). Bacterial colonization of cotton was detected both on the root surface and on root-hairs. Roothair colonization was mainly in the form of small or larger microcolonies (data not shown). Colonization of cotton roots was characterized by two types: small aggregates randomly dispersed in the elongation zone (Fig. $3 a$ ), and single cells connected by a dense fibrillar material to the root surface (Fig. $3 b, c$ ). Microcolonies located at wide-angle cavities on the roots anchored themselves to both sides of the root cavity by a network of fibrillar material. The cells in the microcolony were also connected to each other by this fibrillar material (Fig. $3 d, e$ ). Anchoring of microcolonies to cotton roots was very common.

Effect of watering regime on morphology of A. brasilense $C d$ colonizing the roots of soybean plants

Under regular irrigation the $A$. brasilense $\mathrm{Cd}$ population on the root surface increased exponentially, reaching $10^{6}$ c.f.u. (cm root surface) ${ }^{-1} 20 \mathrm{~d}$ after sowing (Fig. $4 a$ ). Nearly all the bacterial cells observed on the root surface were single vibroid (V-form) forms (Fig. 5a). $A$. brasilense $\mathrm{Cd}$ cells were connected to each other within the small microcolonies and to the root surface by a network of fibrillar material strands (Fig. 5b, arrows). Stopping the irrigation of soybean seedlings affected both the population size and the bacterial cell shape. During the dry period, the number of $A$. brasilense $\mathrm{Cd}$ cells decreased to a low level, i.e. $10^{4}$ c.f.u. (cm root) $)^{-1}$, and the remaining cells were C-forms (Fig. $4 c$, Fig. $5 c$, $d$ ). Restarting irrigation of the plants resulted in the size of the bacterial population increasing $6 \mathrm{~d}$ later (Fig. $4 c$ ) and the bacteria observed were V-form (Fig. 4c, Fig. 5e). Twenty-six days after inoculation, $A$. brasilense $C d$ cells were V-forms, although a few cells kept their $\mathrm{C}$-form throughout the experiment (Fig. $4 c$, Fig. $5 f$ ).

When no water was applied to the seeds until $8 \mathrm{~d}$ after sowing, C-forms appeared $3 \mathrm{~d}$ after sowing (Fig. $4 d$ ). In both irrigation regimes, the $A$. brasilense $C \mathrm{~d}$ population continued to increase for $2-3 \mathrm{~d}$ after the cessation of 

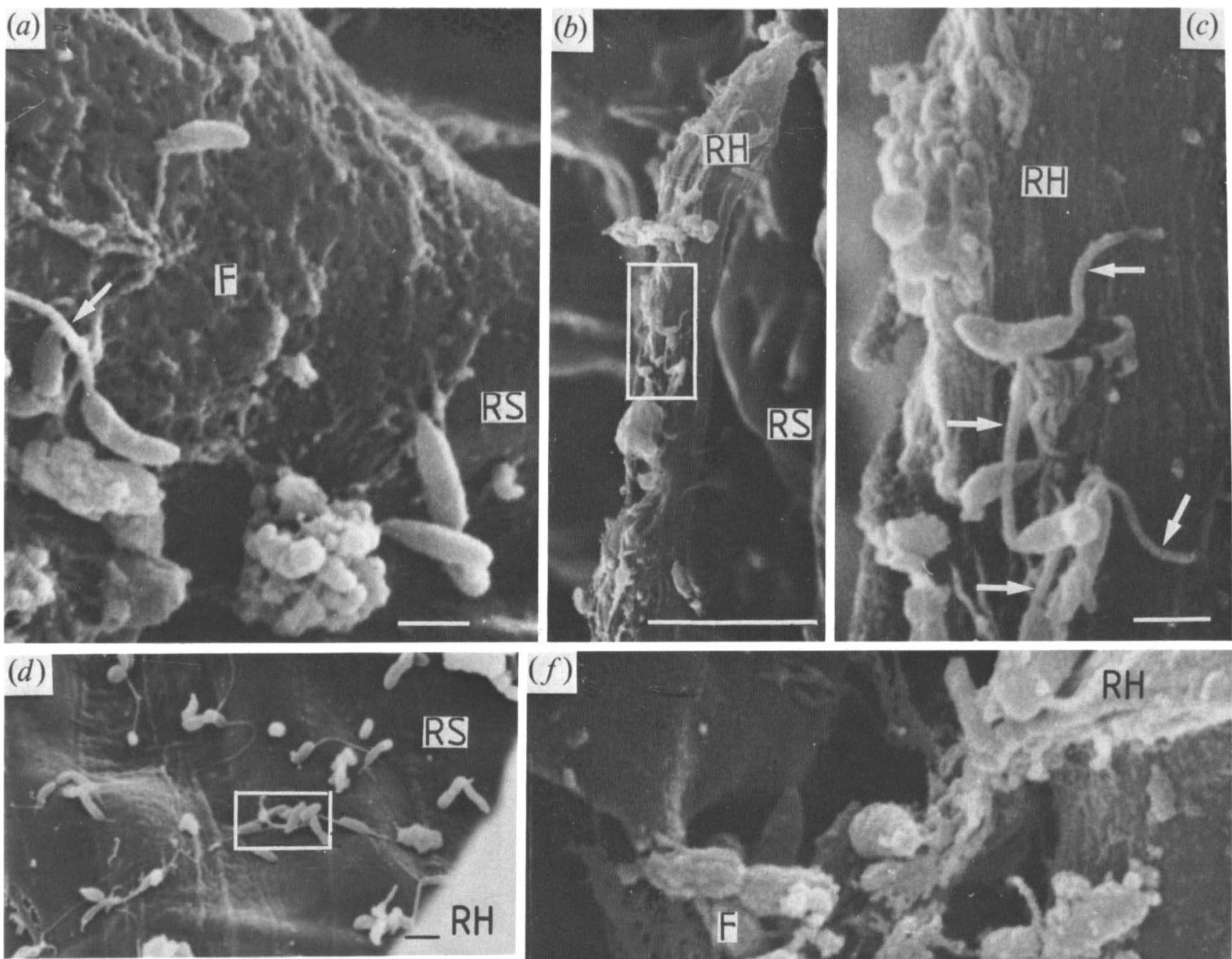

(e)
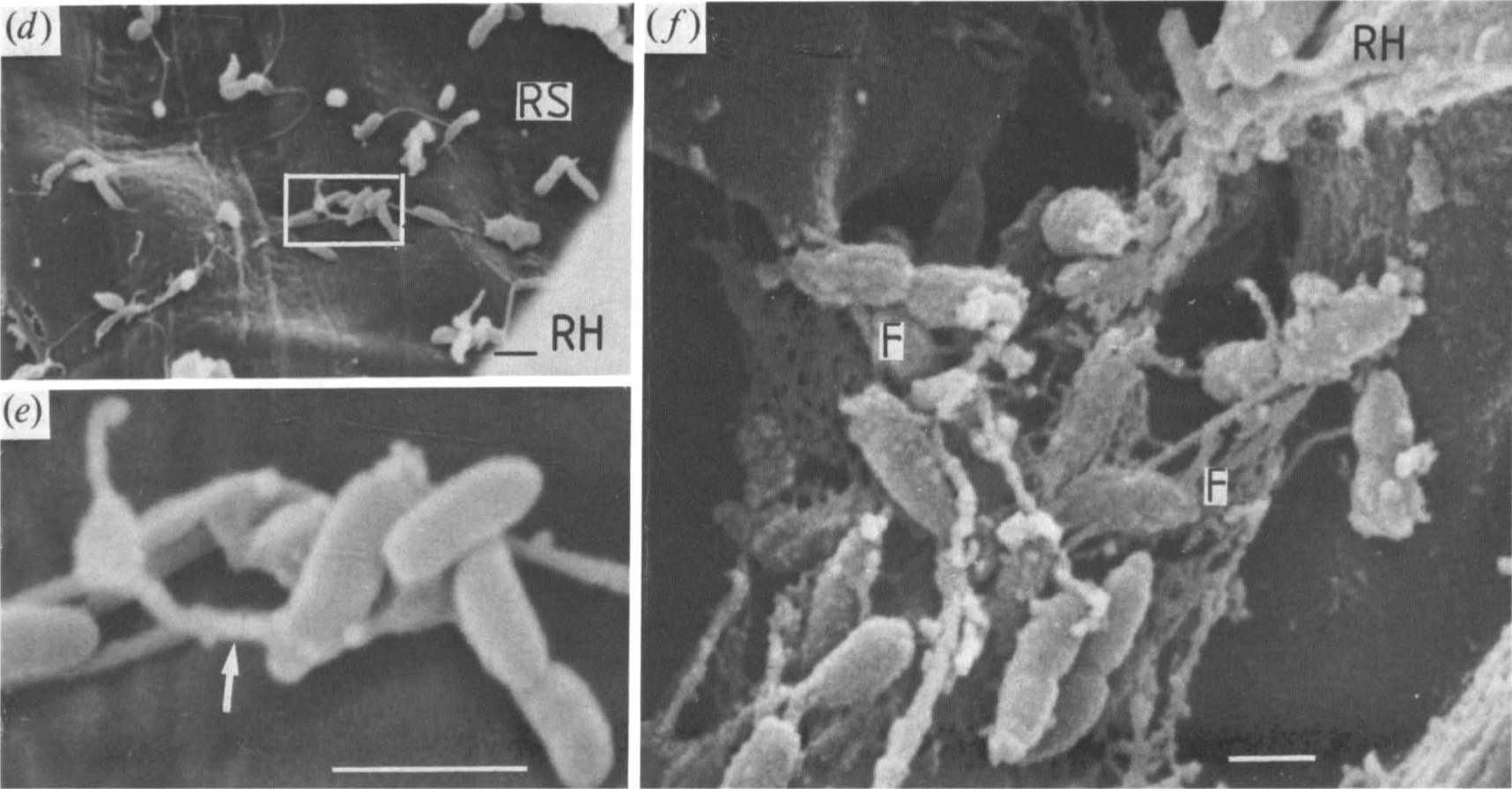

Fig. 2. SEMs of pepper root colonization by $A$. brasilense Cd. (a) Single bacteria colonizing the root surface - note large amounts of mucilaginous substances on the root surface; $(b)$ root hair colonized by bacteria; $(c)$ enlargement of $(b)$ showing connection between bacteria and root-hair surface by thick fibrillar material (arrows); $(d)$ typical mode of colonization on root surface as small aggregates; $(e)$ enlargement of $(d)$ showing the cells connected to each other and to the root by fibrillar material (arrow); $(f)$ microcolony on a roothair - note the large amounts of mucilaginous substances and fibrillar material connecting the microcolony to the root-hair. Bars represent $1 \mu \mathrm{m}(a, c-e)$ and $10 \mu \mathrm{m}(b)$. 

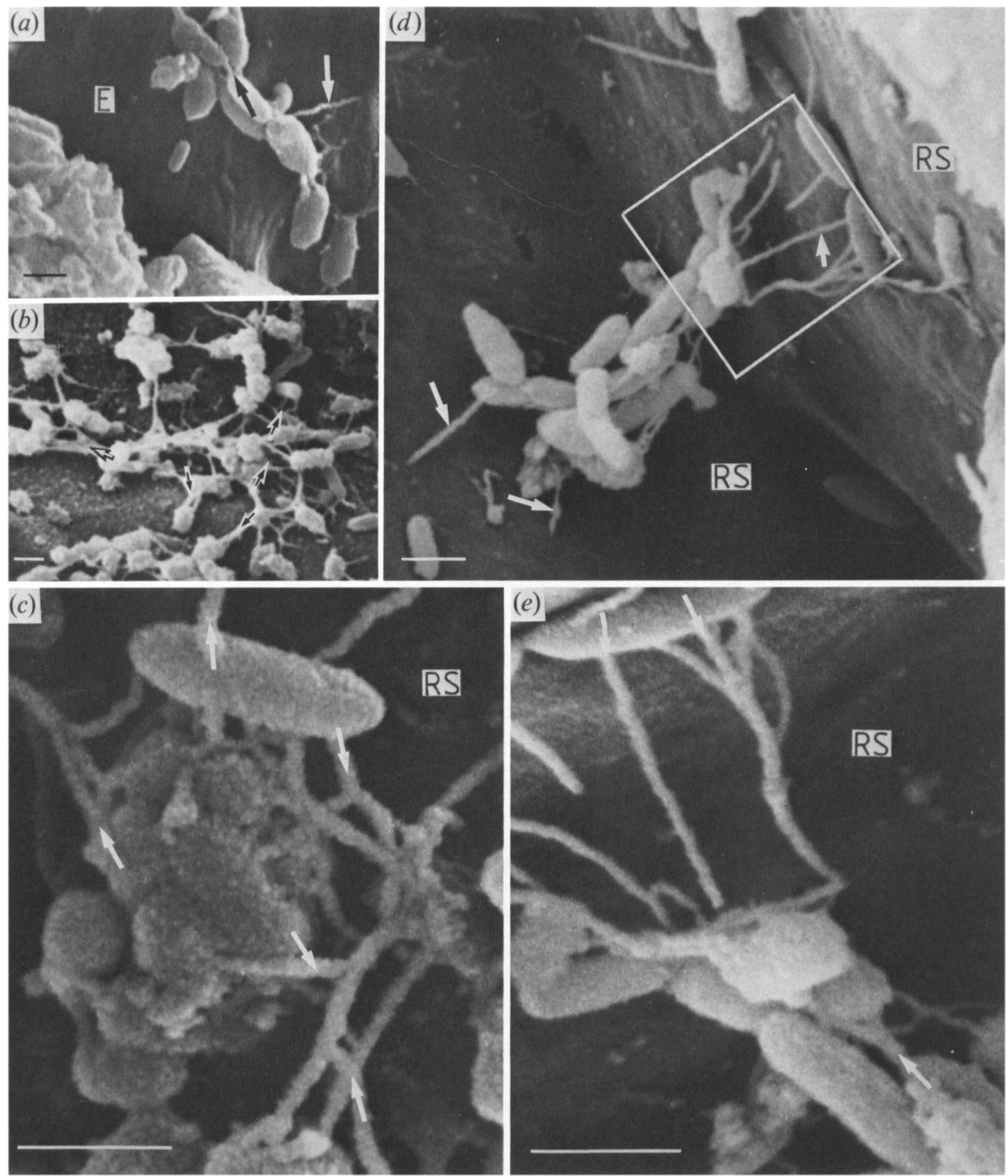

Fig. 3. SEMs of the interaction between $A$. brasilense $\mathrm{Cd}$ cells and cotton roots. (a) First type of colonization, as small aggregates randomly dispersed in the elongation zone; $(b)$ second type of root colonization, as single cells connected by a dense fibrillar material (arrows); (c) higher magnification of a few cells in (b) showing the thick fibrillar material (arrows); $(d)$ microcolony located at a wideangle cavity in the root. Note the microcolony anchored to both sides of the cavity by a network of fibrillar material (arrows); (e) enlargement of $(d)$ - note that cells in the microcolony are connected to each other by fibrillar material (arrow). Bars represent $1 \mu \mathrm{m}$. 

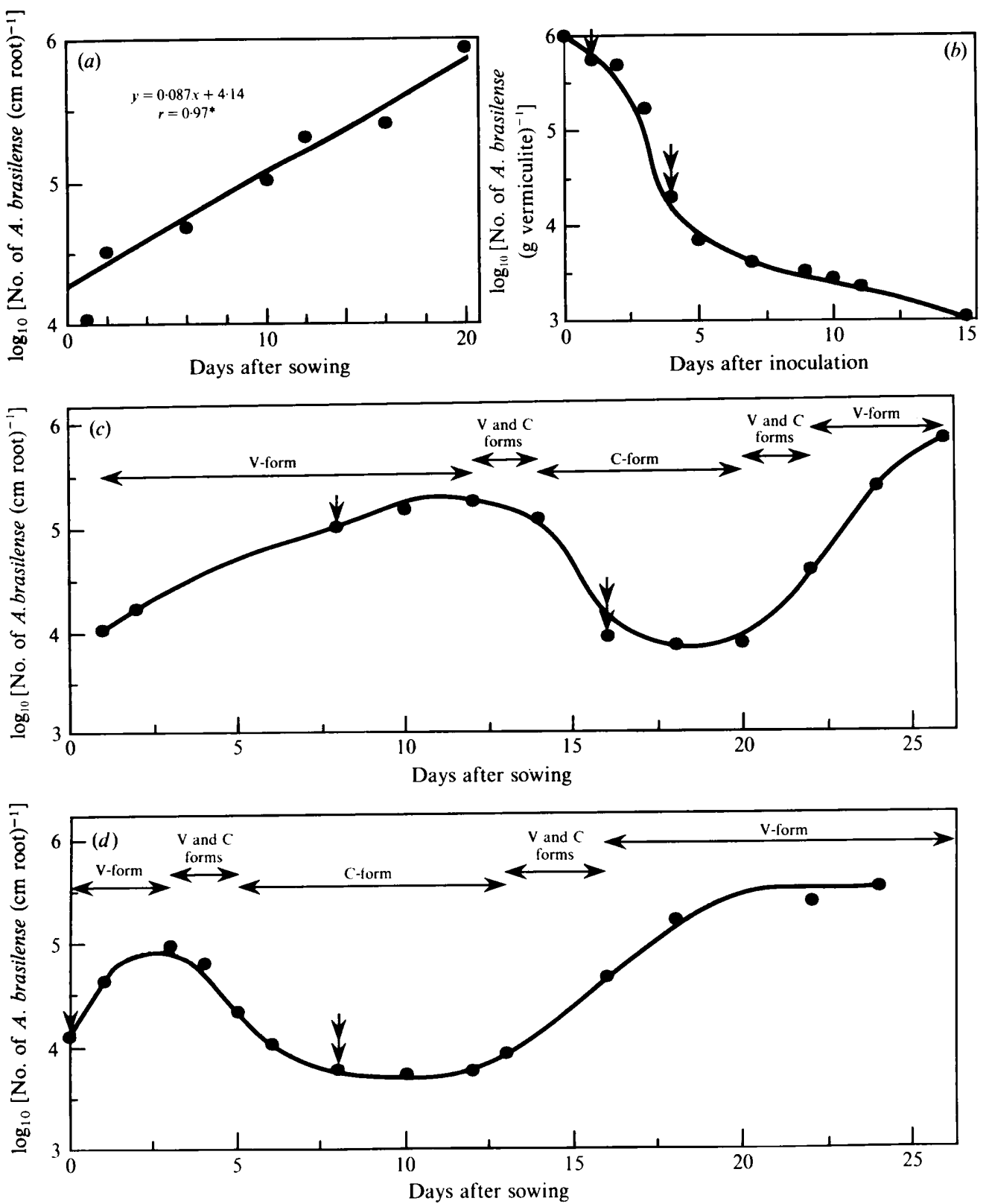

Fig. 4. Colonization of soybean roots $(a, c, d)$ and vermiculite $(b)$ by $A$. brasilense $C d$ under normal growth conditions without water limitation $(a)$, and under water stress $(b, c, d)$. $\downarrow$, Daily irrigation was stopped; $\downarrow$, irrigation renewed. Horizontal bars indicate the form of $A$. brasilense $\mathrm{Cd}$ cells found in this period of time (V, vibrio form; $\mathrm{C}$, cyst form). * indicates significance of a correlation at $P \leq 0.05$.

watering and was composed mainly of V-form cells. Due to changes in the irrigation regimes, there were intermediate periods having $\mathrm{V}$ - and $\mathrm{C}$-form $A$. brasilense $\mathrm{Cd}$ populations. In the absence of plants, the $A$. brasilense $\mathrm{Cd}$ population in the vermiculite decreased sharply regardless of the irrigation regime, reaching a low level $\left[10^{3}\right.$ c.f.u. (g vermiculite) $\left.{ }^{-1}\right]$ after $15 \mathrm{~d}$, a decrease of $99.9 \%$ compared with the original population (Fig. $4 b$ ).
Survival of $V$ - and $C$-forms of $A$. brasilense $C d$ from liquid culture and soybean roots following desiccation

Survival post-desiccation of $\mathrm{V}$-form $A$. brasilense $\mathrm{Cd}$ either from liquid culture or from soybean roots was poor $\left(1.9 \times 10^{2}\right.$ c.f.u. out of $10^{8}$ c.f.u. $\mathrm{ml}^{-1}$ or $2.25 \times 10^{2}$ compared to $10^{6}$ c.f.u. (g root) $)^{-1}$ on non-desiccated roots: Fig. 6). C-form bacteria survived better: $10^{4}$ c.f.u. out of 

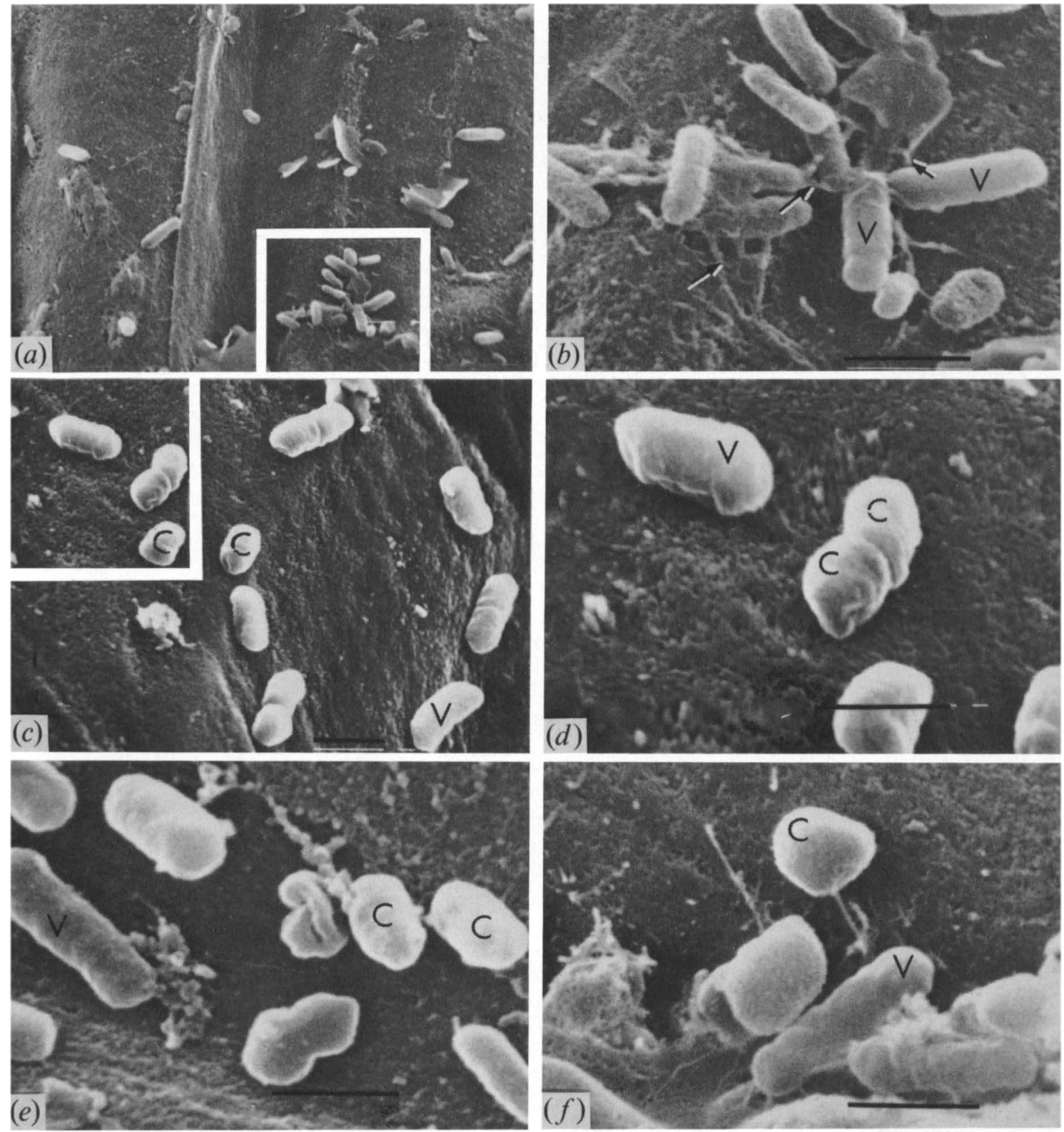

Fig. 5. SEMs of soybean root colonization by A. brasilense Cd. (a) Typical colonization of soybean root surfaces by single cells accompanied by small aggregates; nearly all the cells are of V-form; $(b)$ enlargement of $(a)$ showing bacteria connected to the root surface and to adjacent bacteria by a network of fibrillar material (arrows); (c) colonization of wilting soybean roots composed of $\mathrm{V}$ - and $\mathrm{C}$-forms of $A$. brasilense $\mathrm{Cd} ;(d)$ enlargement of $(c)$ showing the typical shape of $\mathrm{C}$-form bacteria; $(e)$ surface root colonization of wilting soybean roots $2 \mathrm{~d}$ after reapplication of water, showing a mixed population of $\mathrm{V}$ - and $\mathrm{C}$-forms; no fibrillar material is visible; $(f)$ similar to $(e)$ but $8 \mathrm{~d}$ after water application, showing that although most cells are $\mathrm{V}$-form, a few $\mathrm{C}$-form cells remain. Bars represent $1 \mu \mathrm{m}$.

$10^{8}$ c.f.u. $\mathrm{ml}^{-1}$ from liquid culture and $5 \cdot 1 \times 10^{4}$ c.f.u. compared to $10^{6}$ c.f.u. (g root) $)^{-1}$ on non-desiccated roots (Fig. 6).

\section{Discussion}

Most studies of cereal root colonization by Azospirillum have indicated that the mode of colonization is similar in all species studied, involving small aggregates or single cells concentrated mainly on the surface of the root tips and the elongation and root-hair zones, with relatively few cells attached to the root-hairs (Bashan \& Levanony, $1989 a, b$; Bashan et al., 1986). A degree of intercellular root colonization has also been reported (Levanony et al., 1989; Patriquin et al., 1983). Although there is evidence 


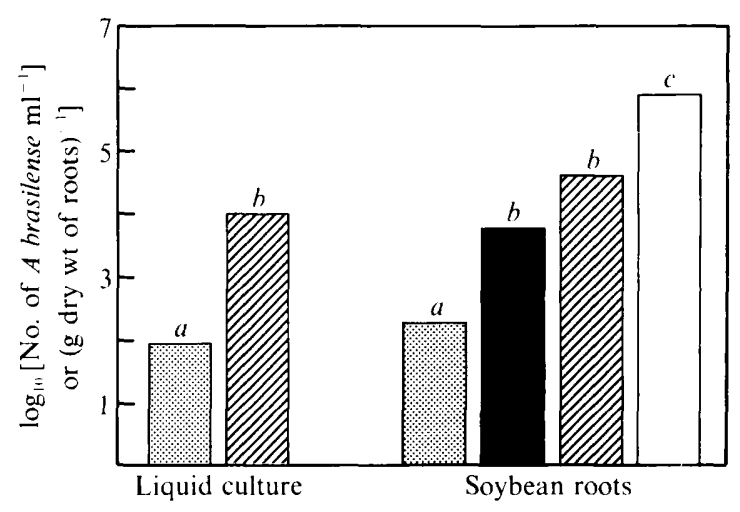

Fig. 6. Survival of $A$. brasilense Cd V-form ( $\square$ ) and C-form ( $\square$ ) after desiccation of liquid medium and soybean roots. The initial number of bacteria in liquid medium was $10^{8}$ c.f.u. $\mathrm{ml}^{-1}$ and roots were inoculated with $10^{7}$ c.f.u. $\mathrm{ml}^{-1} . \square$, Number of $A$. brasilense $\mathrm{Cd}$ in viable nondesiccated roots; $\boldsymbol{\square}$, mixed populations of $\mathrm{V}$ - and $\mathrm{C}$-forms of $\boldsymbol{A}$. brasilense $\mathrm{Cd}$ detected $8 \mathrm{~d}$ after inoculation. Columns with different letters differ significantly at $P \leq 0.05$ in LSD analysis.

that Azospirillum is capable of colonizing and affecting the growth of crop plants other than cereals (Bashan \& Levanony, 1988c; Bashan et al., 1989a, b; Kolb \& Martin, 1985; Saha et al., 1985), the mode of root colonization of these plants has not been determined. This study, which is complementary to our previous one (Bashan et al., 1989a), provides additional evidence that $A$. brasilense $\mathrm{Cd}$ is able to colonize the roots of crop plants belonging to four different families in addition to the Graminaceae. Unlike the uniformity of cereal root colonization between species, colonization of plant roots from other families differs from one plant species to another. Colonization characteristics (mainly root surface, mainly root-hairs, or both) varied from species to species. Nevertheless, as with many cereal roots (Bashan et al., 1986; Bashan \& Levanony, $1989 b$; Levanony \& Bashan, 1989), $A$. brasilense Cd preferentially colonized the elongation and the root-hair zones and not the older parts of the root system as suggested for sorghum (Baldani et al., 1986).

A unique feature of Azospirillum root colonization is the anchoring of bacterial cells to the plant surface by a network of fibrillar material. Fibrillar connections may play a role in the life cycle of $A$. brasilense $\mathrm{Cd}$, whether it is on soil and sand (Bashan \& Levanony, $1988 a, b$ ), wheat (Bashan et al., 1986; Levanony et al., 1989) or on several other non-cereal roots, as demonstrated in the present study. This typical characteristic of Azospirillum should be further evaluated in other plant-growth-promoting rhizobacteria in order to determine if it is a general feature of root colonization by beneficial bacteria.

Pleomorphism (vibroid or cyst-like forms of the bacterial cell) of Azospirillum in in vitro culture is well documented. In the description of the genus Azospiril- lum, pleomorphism was noted upon transfer to $\mathrm{N}$-free medium for several weeks (Tarrand et al., 1978) as well as in the description of the strain used in this study $(\mathrm{Cd})$ (Eskew et al., 1977). Pleomorphism in liquid culture was displayed by many strains isolated from roots of several grasses. Upon prolonged incubation, these isolates produced thick-walled, cyst-like structures which were more resistant to desiccation than normal vegetative cultures (Becking, 1985; Bleakley et al., 1988; Lamm \& Neyra, 1981; Sadasivan \& Neyra, 1985, 1987). C-forms were also induced when Azospirillum cells were subjected to high temperature (Murray \& Moyles, 1987) or to the presence of an insecticide (Mano et al., 1988). Most of the $A$. brasilense $\mathrm{Cd}$ cells in aggregates formed in liquid medium were $\mathrm{C}$-forms which had originated from a Vform inoculum (Madi et al., 1988), and mutants deficient in this transition ability have been isolated (Bastarrachea et al., 1988). Both types of cells have been found in sugarcane callus tissue (Berg et al., 1979, 1980). The dominant cell type in the intercellular spaces of wheat was the C-form, whereas the cells on the surface were Vform (Levanony et al., 1989). The current study shows that this pleomorphism occurred in situ in the rhizosphere. Transition from the vegetative vibroid form to the cyst-like form and vice versa was observed following manipulation of water availability. The mode of this transition remains unknown.

Vegetative cells of Azospirillum survive poorly in soil in the absence of plants (Bashan \& Levanony, 1988 $a$; Smith et al., 1984) but survive for long periods in the rhizosphere of cereal plants even under prolonged dry conditions (Jagnow, 1982). This study provides evidence that $\mathrm{C}$-form bacteria are significantly more resistant to desiccation than V-forms, both in culture and on roots. Thus, the capacity for production of C-form bacteria may represent a valuable survival mechanism by which Azospirillum can persist in the rhizosphere during unfavourable environmental conditions.

This paper was written in memory of the late Mr Avner Bashan. We thank Professor C. Leben, Ohio Agricultural Research and Development Center, Wooster, Ohio, USA, for critical reading of the manuscript. Salaries and research support were provided by State and Federal funds appropriated to the Agricultural Research and Development Center, The Ohio State University.

This is manuscript no. 175-89 from the Ohio Agricultural Research and Development Center, Ohio State University, USA.

\section{References}

Baldani, V. L. D., Alvarez, A. M. DE B., Baldani, J. I. \& DöBEREINER, J. (1986). Establishment of inoculated Azospirillum spp. in the rhizosphere and roots of field grown wheat and sorghum. Plant and Soil 90, 35-46.

BASHAN, Y. (1986). Significance of timing and level of inoculation with rhizosphere bacteria on wheat plants. Soil Biology and Biochemistry 18, 297-301. 
Bashan, Y. \& Levanony, H. (1985). An improved selection technique and medium for the isolation and enumeration of Azospirillum brasilense. Canadian Journal of Microbiology 31, 947-952.

Bashan, Y. \& LeVANONY, H. (1987). Horizontal and vertical movement of Azospirillum brasilense $\mathrm{Cd}$ in the soil and along the rhizosphere of wheat and weeds in controlled and field environments. Journal of General Microbiology 133, 3473-3480.

Bashan, Y. \& LeVANONY, H. (1988a). Adsorption of the rhizosphere bacterium Azospirillum brasilense $\mathrm{Cd}$ to soil, sand and peat particles. Journal of General Microbiology 134, 1811-1820.

Bashan, Y. \& LeVANONY, H. (1988b). Active attachment of Azospirillum brasilense $\mathrm{Cd}$ to quartz sand and to light textured soil by protein bridging. Journal of General Microbiology 134, 2269-2279.

Bashan, Y. \& LeVANONY, H. (1988c). Migration, colonization and adsorption of Azospirillum brasilense to wheat roots. In Lectins Biology, Biochemistry, Clinical Biochemistry, vol. 6, pp. 69-84. Edited by T. C. Bøg-Hansen \& D. L. J. Freed. St Louis, Missouri: Sigma Chemical Co.

Bashan, Y. \& LeVanony, H. (1989a). Wheat root tips as a vector for passive vertical transfer of Azospirillum brasilense Cd. Journal of General Microbiology 135, 2899-2908.

BASHAN, Y. \& LeVANONY, H. (1989b). Factors affecting adsorption of Azospirillum brasilense $\mathrm{Cd}$ to root hairs as compared with root surface of wheat. Canadian Journal of Microbiology 35, 936-944.

Bashan, Y. \& LeVanony, H. (1990). Current status of Azospirillum inoculation technology: Azospirillum as a challenge for agriculture. Canadian Journal of Microbiology 36, 591-608.

Bashan, Y. LeVanony, H. \& Klein, E. (1986). Evidence for a weak active external adsorption of Azospirillum brasilense $\mathrm{Cd}$ to wheat roots. Journal of General Microbiology 132, 3069-3073.

Bashan, Y., ReAm, Y., LevanONy, H. \& SADE, A. (1989a). Nonspecific responses in plant growth, yield, and root colonization of noncereal crop plants to inoculation with Azospirillum brasilense Cd. Canadian Journal of Botany 67, 1317-1324.

Bashan, Y., Singh, M. \& Levanony, H. (1989b). Contribution of Azospirillum brasilense Cd to growth of tomato seedlings is not through nitrogen fixation. Canadian Journal of Botany 67, 2429-2434.

Bashan, Y., Harrison, S. K. \& WhITMOYER, R. E. (1990). Enhanced growth of wheat and soybean plants inoculated with Azospirillum brasilense is not necessarily due to general enhancement of mineral uptake. Applied and Environmental Microbiology 56, 769-775.

Bastarrachea, F., Zamudio, M. \& Rivas, R. (1988). Non-encapsulated mutants of Azospirillum brasilense and Azospirillum lipoferum. Canadian Journal of Microbiology 34, 24-29.

BeCKING, J. H. (1985). Pleomorphism in Azospirillum. In Azospirillum III: Genetics, Physiology, Ecology, pp. 243-262. Edited by W. Klingmüller, Berlin : Springer Verlag.

BeRG, R. H., VAsIl, V. \& VASIL, I. K. (1979). The biology of Azospirillum-sugarcane association. II. Ultrastructure. Protoplasma $101,143-163$.

Berg, R. H., Tyler, M. E., Novick, N. J., Vasil, V. \& Vasil, I. K. (1980). Biology of Azospirillum-sugarcane association: enhancement of nitrogenase activity. Applied and Environmental Microbiology 39, $642-649$.

Bleakley, B. H., Gaskins, M. H., Hubbell, D. H. \& Zam, S. G. (1988). Floc formation by Azospirillum lipoferum grown on poly- $\beta$ hydroxybutyrate. Applied and Environmental Microbiology 54, 2986-2995.

Crossman, S. M. \& Hill, W. A. (1987). Inoculation of sweet potato with Azospirillum. HortScience 22, 420-422.

Eskew, D. L., Focht, D. D. \& TiNG, I. P. (1977). Nitrogen fixation, denitrification, and pleomorphic growth in a highly pigmented Spirillum lipoferum. Applied and Environmental Microbiology 34, 582-585.
JAGNOW, G. (1982). Growth and survival of Azospirillum lipoferum in soil and rhizosphere as influenced by ecological stress conditions. In Azospirillum: Genetics, Physiology, Ecology, pp. 100-107. Edited by W. Klingmüller. Basel: Birkhäuser Verlag.

KolB, W. \& MARTIN, P. (1985). Response of plant roots to inoculation with Azospirillum brasilense and to application of indole acetic acid. In Azospirillum III: Genetics, Physiology, Ecology, pp. 215-221. Edited by W. Klingmüller. Berlin: Springer-Verlag.

LAMM, R. B. \& NeYRA, C. A. (1981). Characterization and cyst production of azospirilla isolated from selected grasses growing in New Jersey and New York. Canadian Journal of Microbiology 27, $1320-1325$

LEVANONY, H. \& Bashan, Y. (1989). Enhancement of cell division in wheat root tips and growth of root elongation zone induced by Azospirillum brasilense Cd. Canadian Journal of Botany 67, 2213-2216.

Levanony, H., Bashan, Y., Romano, B. \& Klein, E. (1989). Ultrastructural localization and identification of Azospirillum brasilense $\mathrm{Cd}$ on and within wheat roots by immuno-gold labelling. Plant and Soil 117, 207-218.

Madi, L., KesSel, M., Sadovnik, E. \& Henis, Y. (1988). Electron microscopic studies of aggregation and pellicle formation in Azospirillum spp. Plant and Soil 109, 115-121.

Mandimba, G., Heulin, T., Bally, R., Guckert, A. \& Balandreau, J. (1986). Chemotaxis of free-living nitrogen-fixing bacteria towards maize mucilage. Plant and Soil 90, 129-139.

Mano, D. M. S., Matos, A. C. M. \& Langenbach, T. (1988). The effect of Dicofol on morphology, growth and nitrogenase activity of Azospirillum lipoferum. In Azospirillum IV: Genetics, Physiology, Ecology, pp. 159-165. Edited by W. Klingmüller. Berlin: Springer Verlag.

MURRAY, R. G. E. \& MoYLES, D. (1987). Differentiation of the cell wall of Azospirillum brasilense. Canadian Journal of Microbiology 33, 132-137.

Patriquin, D. G., Döbereiner, J. \& Jain, D. K. (1983). Sites and processes of association between diazotrophs and grasses. Canadian Journal of Microbiology 29, 900-915.

Plazinski, J. \& Rolfe, B. G. (1985). Interaction of Azospirillum and Rhizobium strains leading to inhibition of nodulation. Applied and Environmental Microbiology 49, 990-993.

Sadasivan, L. \& NeYra, C. A. (1985). Flocculation in Azospirillum brasilense and Azospirillum lipoferum: exopolysaccharides and cyst formation. Journal of Bacteriology 163, 716-723.

Sadasivan, L. \& Neyra, C. A. (1987). Cyst production and brown pigment formation in aging cultures of Azospirillum brasilense ATCC 29145. Journal of Bacteriology 169, 1670-1677.

Saha, K. C., Sannigrahi, S. \& Mandal, L. N. (1985). Effect of inoculation of Azospirillum lipoferum on nitrogen fixation in rhizosphere soil, their association with roots, yield and nitrogen uptake by mustard (Brassica juncea). Plant and Soil 87, 273-280.

SinGH, C. S. \& SubBa RAO, N. S. (1979). Associative effect of Azospirillum brasilense with Rhizobium japonicum on nodulation and yield of soybean (Glycine max). Plant and Soil 53, 387-392.

Smith, R. L., Schank, S. C., Milam, J. R. \& Baltensperger, A. A. (1984). Responses of Sorghum and Pennisetum species to the $\mathrm{N}_{2}-$ fixing bacterium Azospirillum brasilense. Applied and Environmental Microbiology 47, 1331-1336.

TARRAND, J. J. KRIEG, N. R. \& Döbereiner, J. (1978). A taxonomic study of the Spirillum lipoferum group, with descriptions of a new genus, Azospirillum gen. nov., and two species, Azospirillum lipoferum (Beijerinck) comb. nov. and Azospirillum brasilense sp. nov. Canadian Journal of Microbiology 24, 967-980. 